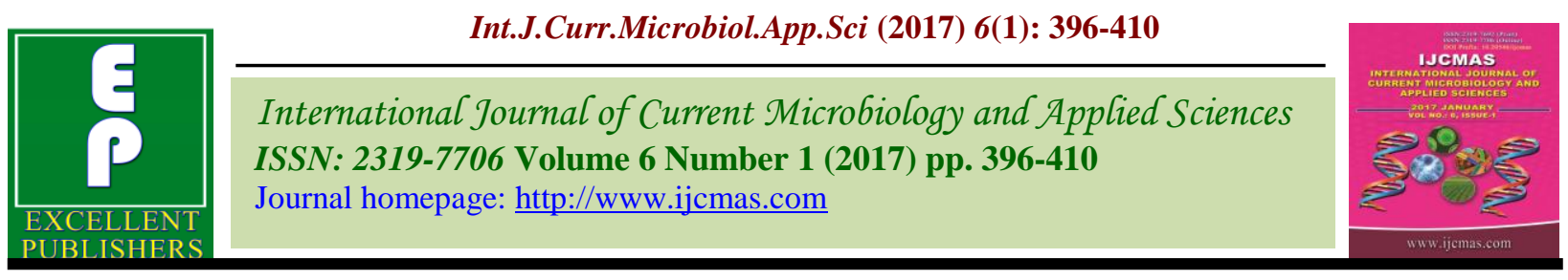

Original Research Article

http://dx.doi.org/10.20546/ijcmas.2017.601.048

\title{
Anti-Virulence Activity of Selected Natural Products against Pseudomonas aeruginosa
}

\author{
Ahmed Ahmed Abd El-Aziz, Tarek El-Said El-Banna, Fatma Ibrahim Sonbol \\ and Shymaa Mohamed Sallam*
}

\begin{abstract}
Pharmaceutical Microbiology Department, Faculty of Pharmacy, Tanta University, Egypt
*Corresponding author
\end{abstract}

\section{A B S T R A C T}

\begin{tabular}{l} 
Key w o r d s \\
$\begin{array}{l}\text { Pseudomonas } \\
\text { aeruginosa, natural } \\
\text { products/extracts, } \\
\text { virulence factors, } \\
\text { outer membrane } \\
\text { proteins. }\end{array}$ \\
\hline Article Info \\
$\begin{array}{l}\text { Accepted: } \\
\text { 23 December } 2016 \\
\text { Available Online: } \\
\text { 10 January } 2017\end{array}$
\end{tabular}

Keywords

Pseudomonas aeruginosa, natura products/extracts, outer membran

\section{Article Info}

Accepted: Available Online

January 2017
Pseudomonas aeruginosa is considered as the epitome of an opportunistic pathogens of hospitalized patients. A total of 159 clinical specimens were recovered and molecular identified by PCR assay. The number of isolates which identified as $P$. aeruginosa was 101 clinical isolates. Considering the effect of 14 natural products/extracts on some virulence factors of MDR isolates, sub inhibitory concentration ( $1 / 2$ MIC) of Syzygium aromaticum (clove) buds extract inhibit the activity of alkaline protease enzyme on skimmed milk agar. The swarming motility was decreased while phospholipase $\mathrm{C}$ enzyme activity was increased by sub inhibitory conc. of clove buds extract. Biofilm formation of $P$. aeruginosa was inhibited by Psidium guajava (guava) leaves extract at $1 / 2$ MIC (showed pink colonies on congo red agar).The effect of different conc. of Psidium guajava leaves extract on outer membrane proteins of Pseudomonas aeruginosa isolate was determined by SDS-PAGE and analyzed using Image J program. Sub inhibitory conc. ( $3 / 4 \mathrm{MIC}$ ) of guava leaves extract showed lower relative density in protein bands at molecular weights of 70 $\mathrm{KDa}, 65 \mathrm{KDa}, 60 \mathrm{KDa}, 59 \mathrm{KDa}, 49 \mathrm{KDa}, 44 \mathrm{KDa} \& 36 \mathrm{KDa}$ compared to the control.

\section{Introduction}

Pseudomonas aeruginosa is a serious opportunistic pathogen in hospitalized patients. The ability of $P$. aeruginosa to cause a wide range of infections is due to the production of a large array of virulence factors (Balasubramanian et al., 2013). Pseudomonas aeruginosa is highly adaptable and have diverse phenotypic characteristics, to inhabit various environmental conditions (Yosuke and Yutaka, 2013). Plant extracts of many plants exhibit antibacterial, antifungal and insecticidal properties under laboratory trails (Okigbo and Ogbonnaya, 2006 and Shariff et al., 2006).
The selection of crude plant extracts for screening programs has the potential of being more successful in its initial steps than the screening of pure individual compounds (Uniyal et al., 2006). Inhibition of bacterial QS can prevent the development of bacterial virulence and successful establishment of infections (Schauder and Bassler, 2001 and Robert et al., 2005). Selected natural products which characterized by QSI in their components will be prepared, extracted and investigated their anti pseudomonal activity against MDR isolates. Furthermore, the effect of the tested natural products/extracts on 
some virulence factors against MDR P.aeruginosa will be investigated. Finally, the analysis of the effect of Psidium guajava (guava) leaves extract on the outer membrane proteins of MDR isolate of $P$. aeruginosa will be investigated.

\section{Material and Methods}

\section{Isolation of bacterial isolates}

The preliminary selection of Pseudomonas aeruginosa isolates was done by culturing each specimen (sputum, urine and pus) on MacConkey's agar (Oxoid, UK) plates and the non lactose fermenting colonies were further sub-cultured on Pseudomonas Cetrimide agar (Oxoid, UK) plates as described byMonica Cheesbrough, (2006).

\section{Molecular identification of the recovered isolates}

\section{DNA Extraction and PCR amplification}

Extraction of bacterial genomic DNA was done by CTAB Method as described by Alexandra, (2009). The purified DNA was amplified using primer highly specific to P.aeruginosa. The forward primer PA431CF was (5'- TGGGTCGAAAGGTGGTTGTTA TC-3') and the reverse primer PA431CR was (5'-GCGGCTGGTGCGGCTGAGTC-3').

PCR amplification was carried out with the following conditions: predenaturation at $95^{\circ} \mathrm{C}$ for $3 \mathrm{~min}$; 35 cycles of denaturation at $95^{\circ} \mathrm{C}$ for $60 \mathrm{sec}$, annealing at $63^{\circ} \mathrm{C}$ for $30 \mathrm{~s}$, and extension at $72^{\circ} \mathrm{C}$ for $60 \mathrm{~s}$ and then final extension step at $72^{\circ} \mathrm{C}$ for $10 \mathrm{~min}$ (Choi and Kim, 2013).

\section{Polyacrylamide gel electrophoresis}

Polyacrylamide gel electrophoresis was performed as described by Han et al. (2008) to separate amplified PCR products. The electrophoresis apparatus was attached to an electric power supply at a constant current of $120 \mathrm{~V}$ for about $80 \mathrm{~min}$.

\section{Polyacrylamide gel staining}

Acrylamide gel was stained by silver nitrate as described by Ji et al. (2007).

\section{Collection, Extraction and Preparation of natural products}

The tested natural products (Mangifera indica (Mango) leaves, Psidium guajava (Guava) leaves, Camellia sinensis (Green tea) leaves, Citrus limon (Lemon) leaves, Cuminum cyminum (Cumin) seeds, Syzygium aromaticum (Clove) flower buds, Bee propolis resin (Bee glue), Sidr Honey, Royal jelly, Zingiber officinale (Ginger) rhizome, Boswellia carterii (Bitter gum) resin, Allium cepa (Onion) bulbs, Panax ginseng roots and Nigella sativa (Black seed) seedswere obtained from local markets in Egypt and extracted with $80 \%$ ethanol as described by Karuppusamy et al. (2009).

\section{Antibiotics susceptibility test}

Antibiogram was performed using commercially available antibiotics disks (Sigma, USA). The tested Pseudomonas aeruginosa isolates were screened for their susceptibility to 16 different antibiotics using disk diffusion method as described by Jan Hudzicki (2009). The inhibition zone diameters were interpreted as susceptible (S), intermediate (I) or resistant (R) according to CLSI 2014guidelines.

\section{MIC and MBC of natural products/extracts}

MIC and MBC of natural products/ extracts were determined against reference P.aeruginosa ATCC 27853 and against 
multidrug resistant isolates $(n=20)$ with MAR $>0.50$ using the broth macrodilution method as described by Carson et al. (1995).

Screening of different virulence factors of $P$. aeruginosa clinical isolates

\section{Swarming motility assay}

Prepared Swarm plates were inoculated by toothpick with individual colonies from a fresh Luria-Bertani (LB) agar plate as described by CheO'May and Nathalie (2011). The inoculum was placed on the agar surface to enable visualization of motility across the agar surface after incubation at $37^{\circ} \mathrm{C}$.

\section{Alkaline protease enzyme assay}

Bacterial isolates of an 18-24 hours old were screened for alkaline protease enzyme as described by Kumar and Jamwal (2013), by inoculating bacterial isolates as spot on skimmed milk agar and incubated for 24 hours at temperature $37^{\circ} \mathrm{C}$. After an incubation period, the diameter of the zone of clearance around the colony, indicating the extent of protease activity.

\section{CTAB-Methylene blue agar assay}

The screening of rhmnolipids producing bacterial isolates was described by Siegmund and Wagner (1991). Rhamnolipids producing colonies on CTAB-Methylene blue agar plates were incubated at $37^{\circ} \mathrm{C}$ for 24 hours and then kept for at least $48 \mathrm{~h}$ at room temperature until a blue halo appeared around colonies as described by Zulianello et al. (2006).

\section{Gelatinase enzyme assay}

A heavy inoculum of an 18-24 hours old at $37^{\circ} \mathrm{C}$ test bacteria was stab-inoculated into tubes containing Nutrient Gelatin as described by Difco \& BBL Manual (2009).

\section{Phospholipase C enzyme assay}

Bacterial isolates of an 18-24 hours old at $37^{\circ} \mathrm{C}$ were screened for Phospholipase $\mathrm{C}$ enzyme as described by McMurray and Magee (1972) Using egg yolk agar which showed an opaque zone due to formation of water-insoluble diglyceride suggesting phospholipase $\mathrm{C}$ activity. Bacterial isolates were incubated for 24 hours at $37^{\circ} \mathrm{C}$. For determination of phospholipase $\mathrm{C}$ enzyme activity, Calculation of the precipitation zone ratio was performed according to Price et al. (1982).

\section{Biofilm formation}

This method is based on the characteristic morphology of biofilm-forming bacteria on Congo red medium as described by Freeman et al. (1989). Plates of the Congo red medium were inoculated and incubated aerobically for 24-48 hours at $37^{\circ} \mathrm{C}$.

The effect of natural products/extracts on tested virulence factors of MDR isolates

All the tested virulence factors were determined by procedures previously described. The treatment of isolates with natural products/extracts was done by adding the natural products/extracts to the molten Muller-Hinton agar in different concentrations.

\section{Effect of Psidium guajava leaves extraction outer membrane proteins profile}

The effect of Psidium guajava leaves extract ( $1 / 4$ MIC, $1 / 2$ MIC and $3 / 4$ MIC) on outer membrane proteins of MDR Pseudomonas aeruginosa isolate was determined by SDSPAGE.

\section{Isolation of outer membrane proteins (OMPs)}

Isolation of outer membranes was carried out as described by Burns and Clark (1992) and 
Nowsheen and Jain (2008). The crude OMP preparation was stored at $-20^{\circ} \mathrm{C}$ till further use.

\section{Protein Estimation}

The protein content in the samples was estimated by Warburg-Christianmethod as described by Warburg and Christian (1941).

Tris-glycine SDS-polyacrylamide gel electrophoresis of outer membrane proteins

Tris-glycine SDS-polyacrylamide gel electrophoresis method was done as described by Sambrook and Russell (2001).

\section{Staining of SDS-PAGE gel}

Reverse staining of SDS-polyacrylamide gel by imidazole-zinc method was used as described by Fernandez-Patron et al. (1992).

\section{Analyzing SDS-PAGE gel}

Image J is a powerful image analysis program that was created at the National Institutes of Health. Image J program was downloaded from the source (http://rsb.info.nih.gov/ij/ ) and Installed on the PC. The analysis steps was described by Tiago and Wayne (2012).

\section{Results and Discussion}

\section{Identification of Pseudomonas aeruginosa clinical isolates}

Only 112 from 159 isolates were grown on Pseudomonas cetrimide agar which considered as preliminary identification of Pseudomonas isolates.After molecular identification by PCR assay,only $P$. aeruginosa isolates showed a single amplified product of $232 \mathrm{bp}$, the number of isolates which identified as $P$. aeruginosa was 101 clinical isolates.

\section{Antibiotics susceptibility test}

The incidence of resistance to 16 different antimicrobials ranged from $2.9 \%$ to $100 \%$. $P$. aeruginosa isolates showed resistance to Ceftazidime(89.1\%), and Azetronam (83.1\%) while the sensitivity was showed to Levofloxacin (93.2\%), Meropenem (84.2\%) and Cefoperazone $(79.3 \%)$.

MIC and MBC of natural products/extracts

Clove buds extract was the most active against MDR isolates in inhibitory concentration mean of $6.5 \% \mathrm{v} / \mathrm{v}$ and bactericidal concentration mean of $13.3 \%$ v/v. Other natural products activity against MDR isolates was shown in Table (1).

\section{Screening of different virulence factors of} $P$. aeruginosa clinical isolates

The Incidence of the tested virulence factors in clinical P.aeruginosaisolates $(\mathrm{n}=101)$ was shown in Figure (1).

\section{The effect of natural products/extracts on swarming motility}

The swarming diameter average of isolates treated with $1 / 2$ MIC of clove extract $=10 \mathrm{~mm}$ in comparison with swarming diameter average of control isolates $=25 \mathrm{~mm}$. Also, $50 \% \mathrm{v} / \mathrm{v}$ of Sidr Honey and $1 / 2$ MIC of green tea leaves extract decreased the swarming activity. Although cumin seeds extract showed no change in swarming diameter at $1 / 2$ MIC \& $1 / 4$ MIC compared to the control $(0 \%)$ but affect the way of swarming pattern from dendrites to bull's eye pattern only at $1 / 2$ MIC as shown in Figure (2).Natural products showed effect on swarming was listed in Table (2) while others unlisted natural products/extracts couldn't affect the swarming motility. 
The effect of natural products/extracts on alkaline protease enzyme activity

The sub inhibitory conc. ( $1 / 2$ MIC) of clove buds extract inhibit the activity of alkaline protease enzyme as the clear zone around colonies $=0 \mathrm{~mm}$ compared to $5 \mathrm{~mm}$ of the control $(0 \%)$ while $(1 / 2$ MIC) of cumin seeds extract decrease in the enzyme activity as shown in Figure (3). Natural products showed effect on alkaline protease activity was listed in Table (3) while others unlisted natural products/extracts couldn't affect the alkaline protease activity.

The effect of natural products/extracts on phospholipase $\mathrm{C}$ enzyme activity

Regarding to phospholipase C enzyme activity, the sub inhibitory conc. of clove buds extract increased the activity of phospholipase $\mathrm{C}$ enzyme in conc. dependent way as the average of the precipitation zone ratio of $(1 / 2$ MIC) $=0.41$ compared to the control average $=0.66$.Also, $50 \% \mathrm{v} / \mathrm{v}$ Sidr honey increase the activity of phospholipase $\mathrm{C}$ as the average of the precipitation zone ratio $=0.41$ compared to the control average $=0.63$. But, Cumin seeds extract decreased the activity of phospholipase $\mathrm{C}$ enzyme from large activity $((\mathrm{Pz}<0.70)$ to poor activity $(\mathrm{Pz}=0.80-0.89)$ as the average of the precipitation zone ratio at $1 / 2$ MIC was 0.81 compared to the control average $=0.45$ as shown in Figure (4).Natural products showed effect on phospholipase $\mathrm{C}$ enzyme activity was listed in Table (4) while others unlisted natural products/extracts couldn't affect the phospholipase enzyme C activity.

\section{The effect of natural products/extracts on biofilm formation}

Guava leaves extract at $1 / 2$ MIC showed pink colonies (inhibition of biofilm formation) while both $1 / 4$ MIC and the control showed black colonies with dry crystalline consistency as shown in Figure(5). Other natural products/extracts showed no effect on biofilm formation at different concentrations.

The effect of natural products/extracts on rhamnolipids production and gelatinase enzyme production

All the tested natural products/extracts couldn't affect the production of both rhamnolipids and gelatinase enzyme.

\section{Effect of Psidium guajava leaves extracton OMPs profile}

The effect of Psidium guajava leaves extract at (1/4 MIC, $1 / 2$ MIC and 3/4 MIC) on outer membrane proteins of MDR Pseudomonas aeruginosa isolate was shown in Figure (6). Analysis of the resulted OMP bands to determine the difference in bandssize and darkness between the control and different treatments of guava leaves extract was done using Image J program. Table (5) showed the summary of relative density of selected protein bands of different concentrations of guava leaves extract compared to the control.

The results showed molecular identification of 101 clinical isolates of Pseudomonas aeruginosaout of 112 isolates which grown on Pseudomonas Cetrimide agar. The timely and accurate information provided by PCR assay would help to identify $P$. aeruginosa bacteremia, and initiate adequate therapy from 18 to $24 \mathrm{~h}$ earlier than with conventional methods (Reischl et al., 2000 and Shrestha et al., 2002). Because standard phenotypic methods are time consuming and have limitations, highly specificmolecular techniques have used to identify bacterial pathogens (Van Delden,2007).

This research primarily focuses on natural products with QS inhibitors components, which display potential for treating bacterial infections. Because of the wide variety of 
molecules present in the natural products/extracts, the antimicrobial activity cannot be attributed to a single mechanism. Instead, different biochemical and structural mechanisms are involved (Carson et al., 2002) at multiple sites within the cell and on the cell surface. (Burt and Reinders, 2003 and Burt, 2004). However, each of these actions cannot be considered separate events but may be a consequence of the other activities. Inhibition of bacterial QS can prevent the development of bacterial virulence and successful establishment of infections (Schauder and Bassler, 2001 and Robert et al., 2005).

Swarming motility plays a critical role in the environmental adaptation of $P$. aeruginosa. The decrease in swarming activity was expected in natural products have QS inhibitor components which interfere with quorum sensing regulation. The way of swarming was changed from dendrites to bull's eye pattern at $1 / 2$ MIC of cumin extract i.e the swarming pattern changed from dendrites which are long regions of colonization emanating from a central origin (Deziel et al., 2003; Caiazza et al., 2005 and Tremblay et al., 2007) to Bull's eye pattern which results from cyclic and synchronous waves of motility followed by regular periods of swarming cessation (Hoeniger, 1964; Rauprich et al., 1996 and Matsuyama et al., 2000). It may be concluded that the changing of this pattern may be due to a mutation related to secreted molecules : 3-(3hydroxyalkanoyloxy) alkanoic acids (HAA) precursor which acts as a repellent and dirhamnolipid that acts as an attractant as (Caiazza et al., 2005 and Tremblay et al., 2007) reported that the dendrites of $P$. aeruginosa result from expansion and repulsion of each other as a result of the complicated interplay between the two secreted molecules.

Pseudomonas aeruginosa secretes alkaline protease (AprA) to enhance its survival. (Bardoel et al., 2011). Alkaline protease of $P$. aeruginosa inactivate human $\gamma$-interferon and human tumor necrosis factor- $\alpha$ (Horvat et al., 1988 and Parmely et al., 1990). $\gamma$-interferon is the key factor for innate and adaptive immunity against different infections and for control of tumor formation. A lack of $\gamma$ interferon results in autoinflammatory and autoimmune diseases (Schroder et al., 2004 and Schoenborn and Wilson, 2007).The obtained results showed inhibition /or decrease of alkaline protease activity which may be due to the quorum quenching properties in the components of tested natural products/ extracts.

Phospholipase $\mathrm{C}$ activity in bacteria treated with sub-inhibitory conc. of clove buds extract, green tea leaves extract and lemon leaves extract was increased. Also, $25 \%$ \& $50 \%$ of ginseng and sidr honey increased the activity of phospholipase $\mathrm{C}$. This results may be due to the expression or upregulation of phospholipase enzyme as a result of QS inhibitors in phytochemicals of the tested natural products/extracts. Sophie et al., (2005) reported that the type III secretion regulon is a negative target for QS in $P$. aeruginosa. This is the first $P$. aeruginosa virulence factor for which a negative regulation by RhlR/I-C4HSL has been demonstrated. Type III secretion system (TTSS) of P.aeruginosa is, apparently, imperative to virulence as it delivers, at least, four exoenzymes into host cells: ExoS, ExoT, ExoU and ExoY(Engel and Balachandran,2009). ExoU is a phospholipase that can cause membrane damage and cell lysis and modulate the inflammatory response (Deng and Barbieri, 2008; Anderson and Frank, 2012).

It may be concluded that QS represses type III secretion regulon, suggests that the associated virulence functions are likely to be repressed i.e: ExoU (phospholipase) is negatively controlled by QS. So, quorum sensing inhibitors may allow the expression or upregulation of ExoU (phospholipase).It may 
be supposed that the increased phospholipase $\mathrm{C}$ activity may alter host defence against P.aeruginosa pathogen as a resulted effect of the tested natural products/extracts.

Moreover, the sub-inhibitory concentration of cumin extract (which also characterized by QSI phytochemicals components as methyl euogenol) showed decreasing in the activity of phospholipase C. The present results are in agreement with these reported by Kusum et al.
(2014), who explored the action of cranberry towards virulence of $P$. aeruginosa through quorum sensing (QS) inhibition and found significant reduction in phospholipase $\mathrm{C}$ in presence of cranberry as compared to control. Meyers and Berk (1990) found that the significant reduction in the level of phospholipase $\mathrm{C}$ helps pathogen to overcome the action of host defence and contributes towards tissue inflammation.

Table.1 Mean of MIC and MBC \pm S.E of natural product extracts against MDR isolates and reference P.aeruginosa ATCC 27853 isolate

\begin{tabular}{|c|c|c|c|c|}
\hline \multirow{2}{*}{$\begin{array}{c}\text { Natural product } \\
\text { extracts }\end{array}$} & \multicolumn{2}{|c|}{$\begin{array}{c}\text { Pseudomonas aeruginosa } \\
\text { ATCC } 27853\end{array}$} & \multicolumn{2}{c|}{ MIDR isolates (n=20) } \\
\cline { 2 - 5 } & MIC (\% v/v) & MBC (\% v/v) & $\begin{array}{c}\text { Mean of MIC } \\
\mathbf{\pm S . E}(\% \mathrm{v} / \mathrm{v})\end{array}$ & $\begin{array}{c}\text { Mean of MBC } \\
\mathbf{\pm} \text { S.E(\%v/v) }\end{array}$ \\
\hline Syzygium aromaticum & 5 & 10 & $6.5 \pm 0.5$ & $13.3 \pm 1.7$ \\
\hline Psidium guajava & 5 & 10 & $8.5 \pm 1.6$ & $16.5 \pm 8.1$ \\
\hline Camellia sinensis & 10 & 15 & $10 \pm 0.0$ & $15 \pm 0.0$ \\
\hline Mangifera indica & 10 & 20 & $13.5 \pm 0.2$ & $38.3 \pm 0.0$ \\
\hline Cuminum cyminum & 20 & 40 & $26.6 \pm 3.5$ & $>50$ \\
\hline Citrus limon & 20 & $>50$ & $27.1 \pm 2.0$ & $>50$ \\
\hline
\end{tabular}

Table.2 Average of swarming colony diameter $(\mathrm{mm})$ of P.aeruginosa isolates treated with different conc. of natural products/extracts

\begin{tabular}{|c|c|c|c|}
\hline $\begin{array}{c}\text { Natural products/ } \\
\text { extracts }\end{array}$ & $\begin{array}{l}0 \% \text { of natural } \\
\text { products/ extracts } \\
\text { (control) }\end{array}$ & $\begin{array}{c}1 / 4 \mathrm{MIC} \text { of } \\
\text { natural } \\
\text { products/extracts }\end{array}$ & $\begin{array}{c}1 / 2 \mathrm{MIC} \text { of } \\
\text { natural } \\
\text { products/extracts }\end{array}$ \\
\hline Clove buds extract & 25 & 18 & 10 \\
\hline Green tea leaves extract & 20 & 15 & 13 \\
\hline Lemon leaves extract & 23 & 25 & 18 \\
\hline Cumin seeds extract & 25 & 25 & 25 \\
\hline $\begin{array}{c}\text { Natural products/ } \\
\text { extracts }\end{array}$ & $\begin{array}{l}0 \% \text { of natural } \\
\text { products/ } \\
\text { extracts(control) }\end{array}$ & $\begin{array}{l}25 \% \text { of natural } \\
\text { products/extracts }\end{array}$ & $\begin{array}{c}50 \% \text { of natural } \\
\text { products/ } \\
\text { extracts }\end{array}$ \\
\hline Bee glue & 18 & 13 & 8 \\
\hline Black seed oil & 20 & 20 & 17 \\
\hline Frankincense & 20 & 20 & 18 \\
\hline Ginger juice & 30 & 25 & 20 \\
\hline Ginseng & 30 & 20 & 15 \\
\hline Sidr honey & 22 & 19 & 10 \\
\hline
\end{tabular}


Table.3 Alkaline protease activity in term of clear zone diameter average $(\mathrm{mm})$ of P.aeruginosa isolates treated with different conc. of natural products/extracts

\begin{tabular}{|c|c|c|c|}
\hline $\begin{array}{c}\text { Natural products/ } \\
\text { extracts }\end{array}$ & $\begin{array}{l}0 \% \text { of natural } \\
\text { products/extracts } \\
\text { (control) }\end{array}$ & $\begin{array}{c}1 / 4 \mathrm{MIC} \text { of } \\
\text { natural } \\
\text { products/extracts }\end{array}$ & $\begin{array}{c}1 / 2 \mathrm{MIC} \text { of } \\
\text { natural } \\
\text { products/extracts }\end{array}$ \\
\hline Clove buds extract & 5 & 2 & 0 \\
\hline Cumin seeds extract & 5 & 4 & 2 \\
\hline Green tea leaves extract & 5 & 5 & 3 \\
\hline Guava leaves extract & 5 & 4 & 2 \\
\hline Natural products & $\begin{array}{l}\mathbf{0 \%} \text { of natural } \\
\text { products(control) }\end{array}$ & $\begin{array}{l}25 \% \text { of natural } \\
\text { products }\end{array}$ & $\begin{array}{l}50 \% \text { of natural } \\
\text { products }\end{array}$ \\
\hline Red Onion juice & 4 & 4 & 3 \\
\hline Sidr honey & 4 & 2 & 2 \\
\hline
\end{tabular}

Table.4 Phospholipase $\mathrm{C}$ activity in term of precipitation zone ratio of P.aeruginosa isolates treated with different conc. of natural products/extracts

\begin{tabular}{|c|c|c|c|}
\hline $\begin{array}{l}\text { Natural products/ } \\
\text { extracts }\end{array}$ & $\begin{array}{l}0 \% \text { of natural } \\
\text { products/ extracts } \\
\text { (control) }\end{array}$ & $\begin{array}{l}1 / 4 \mathrm{MIC} \text { of } \\
\text { natural products } \\
\text { /extracts }\end{array}$ & $\begin{array}{l}1 / 2 \mathrm{MIC} \text { of natural } \\
\text { products/ extracts }\end{array}$ \\
\hline Clove buds extract & $0.66(++++)$ & $0.46(++++)$ & $0.41(++++)$ \\
\hline Cumin seeds extract & $0.45(++++)$ & $0.60(++++)$ & $0.81(++)$ \\
\hline Green tea leaves extract & $0.68(++++)$ & $0.64(++++)$ & $0.52(++++)$ \\
\hline Lemon leaves extract & $0.60(++++)$ & $0.35(++++)$ & $0.35(++++)$ \\
\hline Natural products & $\begin{array}{l}0 \% \text { of natural } \\
\text { products }\end{array}$ & $\begin{array}{l}25 \% \text { of natural } \\
\text { products }\end{array}$ & $\begin{array}{l}50 \% \text { of natural } \\
\text { products }\end{array}$ \\
\hline Ginger juice & $0.53(++++)$ & $0.42(++++)$ & $0.47(++++)$ \\
\hline Ginseng & $0.60(++++)$ & $0.42(++++)$ & $0.38(++++)$ \\
\hline Sidrhoney & $0.63(++++)$ & $0.57(++++)$ & $0.41(++++)$ \\
\hline
\end{tabular}

Fig.1 Incidence of virulence factors in P.aeruginosa isolates

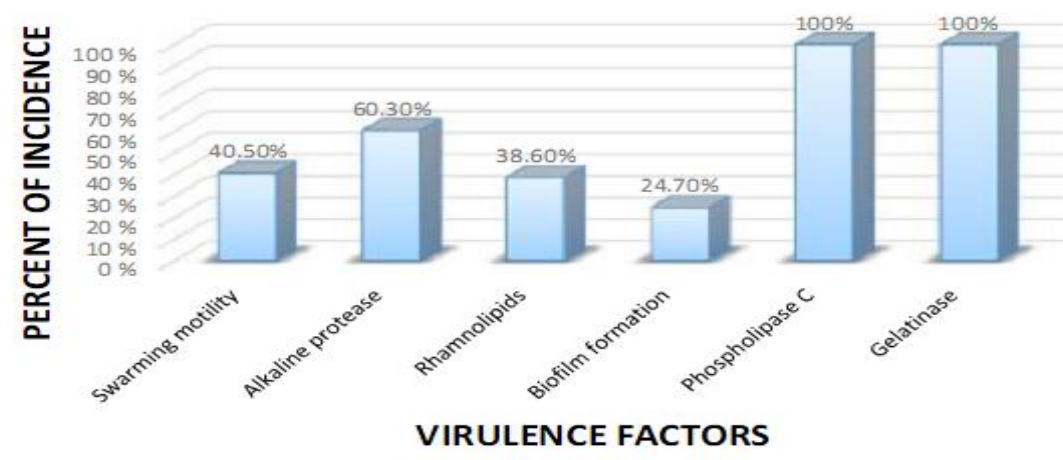


Fig.2 Effect of a-Clove buds b-Sidr Honey c- Green tea leaves d- Cumin seeds on swarming motility

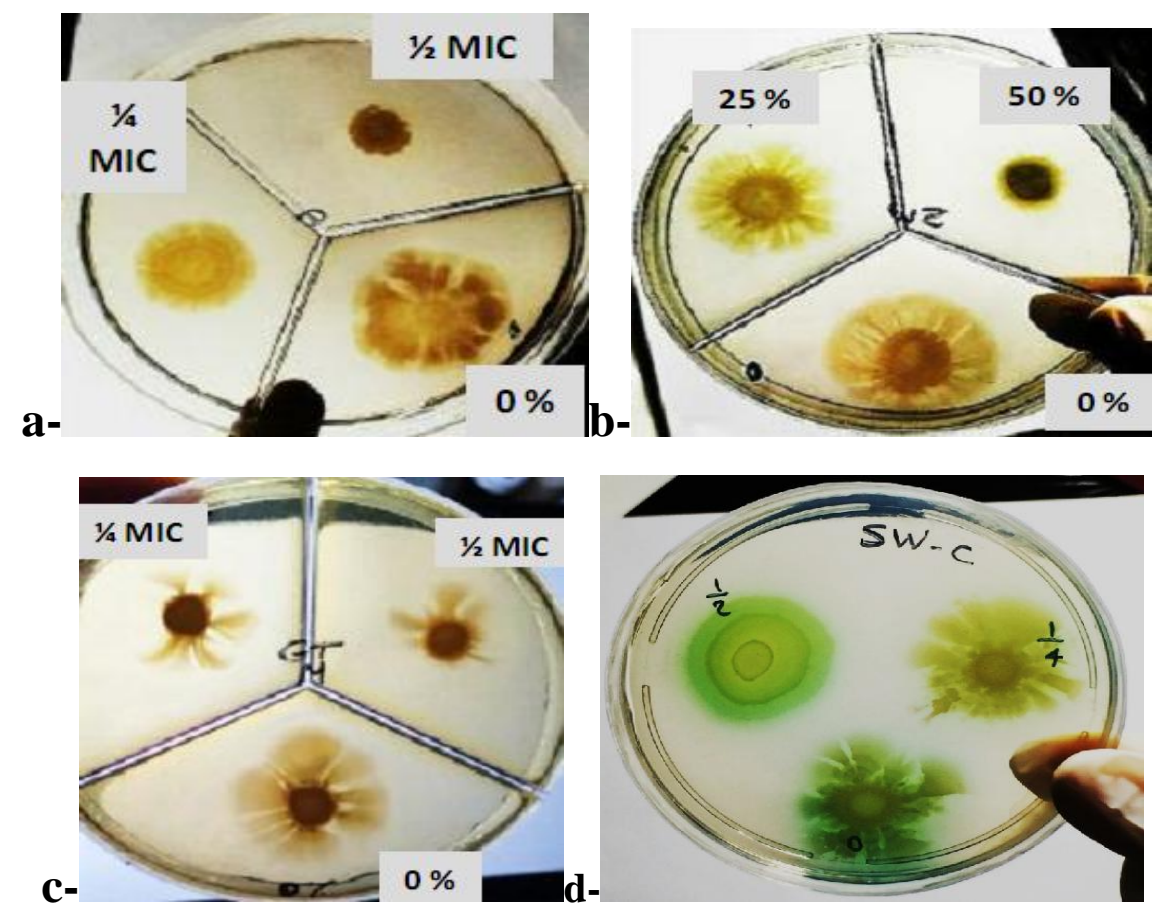

Fig.3 Effect of a-Clove buds b- Cumin seeds on alkaline protease enzyme activity
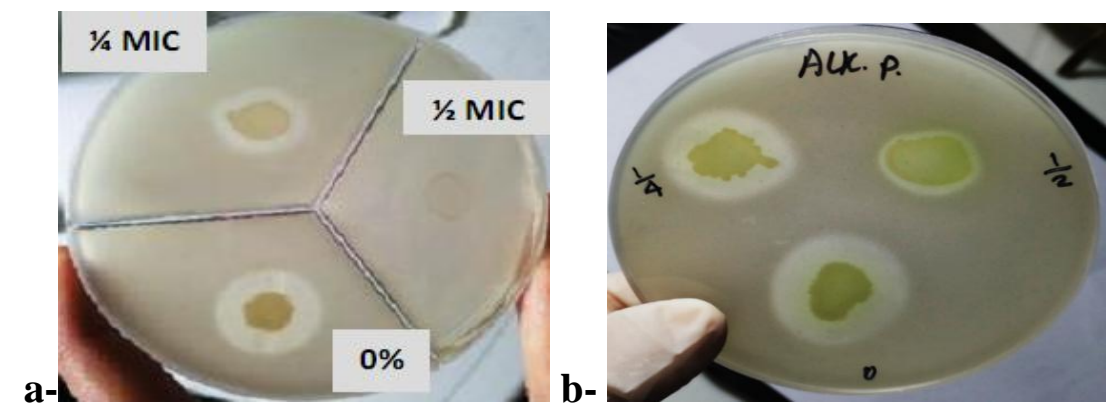

Fig.4 Effect of a-Clove buds b-Sidr honey c- Cumin seeds on phospholipase C enzyme

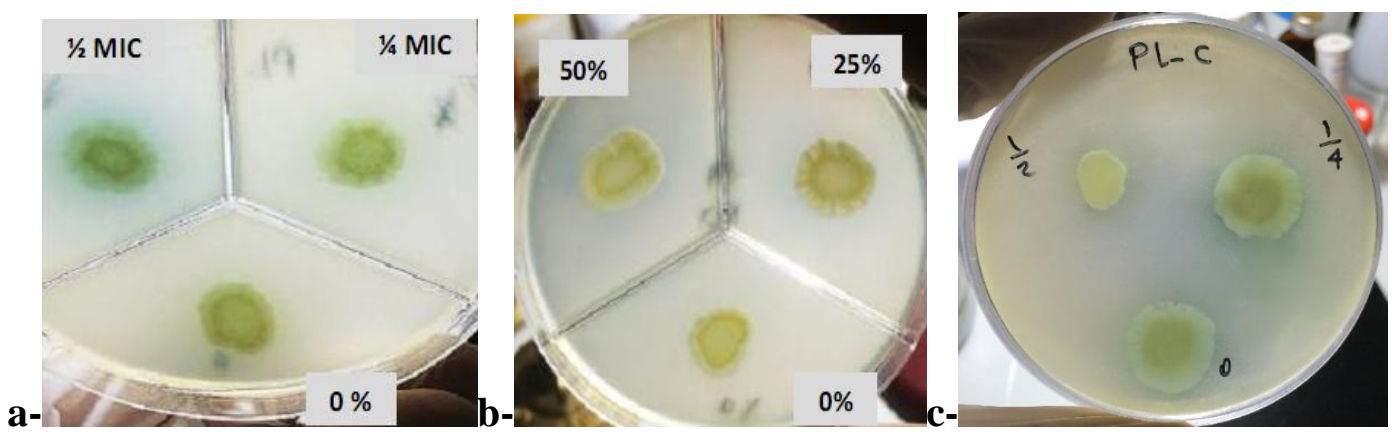


Table.5 The summary of relative density of OMP bands

\begin{tabular}{|c|c|c|c|c|}
\hline & \multicolumn{5}{|c|}{ Relative density } \\
\hline $\mathbf{M r}(\mathrm{KDa})$ & Untreated & $\begin{array}{c}\mathbf{2 . 5 \%} \text { Guava } \\
\text { leaves extract }\end{array}$ & $\begin{array}{c}\mathbf{5 \%} \text { Guava } \\
\text { leaves extract }\end{array}$ & $\begin{array}{c}\mathbf{7 . 5 \%} \text { Guava } \\
\text { leaves extract }\end{array}$ \\
\hline 115 & 1 & 1.096 & 1.093 & $\mathbf{1 . 1 5 4}$ \\
\hline 107 & 1 & 0.733 & $\underline{\mathbf{0 . 6 1 2}}$ & 0.621 \\
\hline 89 & 1 & 0.640 & $\underline{\mathbf{0 . 5 1 9}}$ & 0.530 \\
\hline 70 & 1 & 0.566 & 0.518 & $\underline{\mathbf{0 . 5 0 5}}$ \\
\hline 65 & 1 & 0.524 & 0.490 & $\underline{\mathbf{0 . 4 5 9}}$ \\
\hline 50 & 1 & 0.489 & 0.458 & $\underline{\mathbf{0 . 4 2 3}}$ \\
\hline 52 & 1 & 0.476 & 0.454 & $\underline{\mathbf{0 . 4 1 4}}$ \\
\hline 49 & 1 & 0.467 & 0.409 & $\underline{\mathbf{0 . 3 7 1}}$ \\
\hline 44 & 1 & 0.511 & 0.438 & $\underline{\mathbf{0 . 4 0 9}}$ \\
\hline 39 & 1 & 0.545 & 0.486 & $\underline{\mathbf{0 . 4 5 9}}$ \\
\hline 38 & 1 & 0.539 & 0.432 & $\underline{\mathbf{0 . 3 5 8}}$ \\
\hline 36 & 1 & 0.634 & 0.542 & $\underline{\mathbf{0 . 4 1 7}}$ \\
\hline & 1 & 0.638 & 0.516 & $\underline{\mathbf{0 . 4 1 0}}$ \\
\hline
\end{tabular}

Fig.5 Inhibition of biofilm formation by $1 / 2$ MIC Psidium guajava leaves extract.

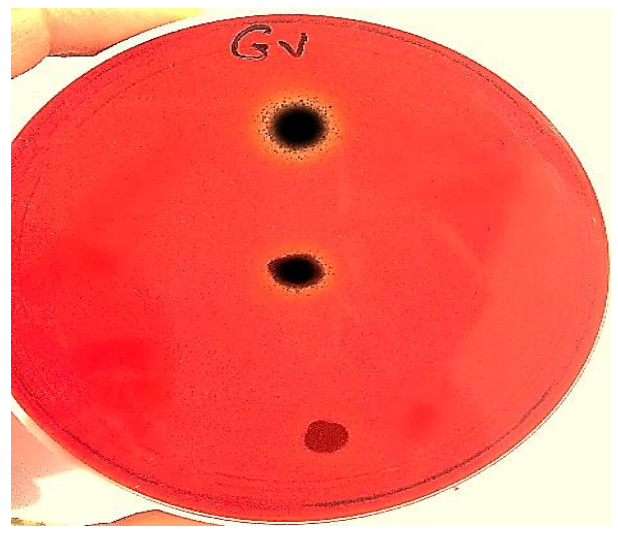


Fig.6 Effect of Psidium guajava leaves extract on OMPs.

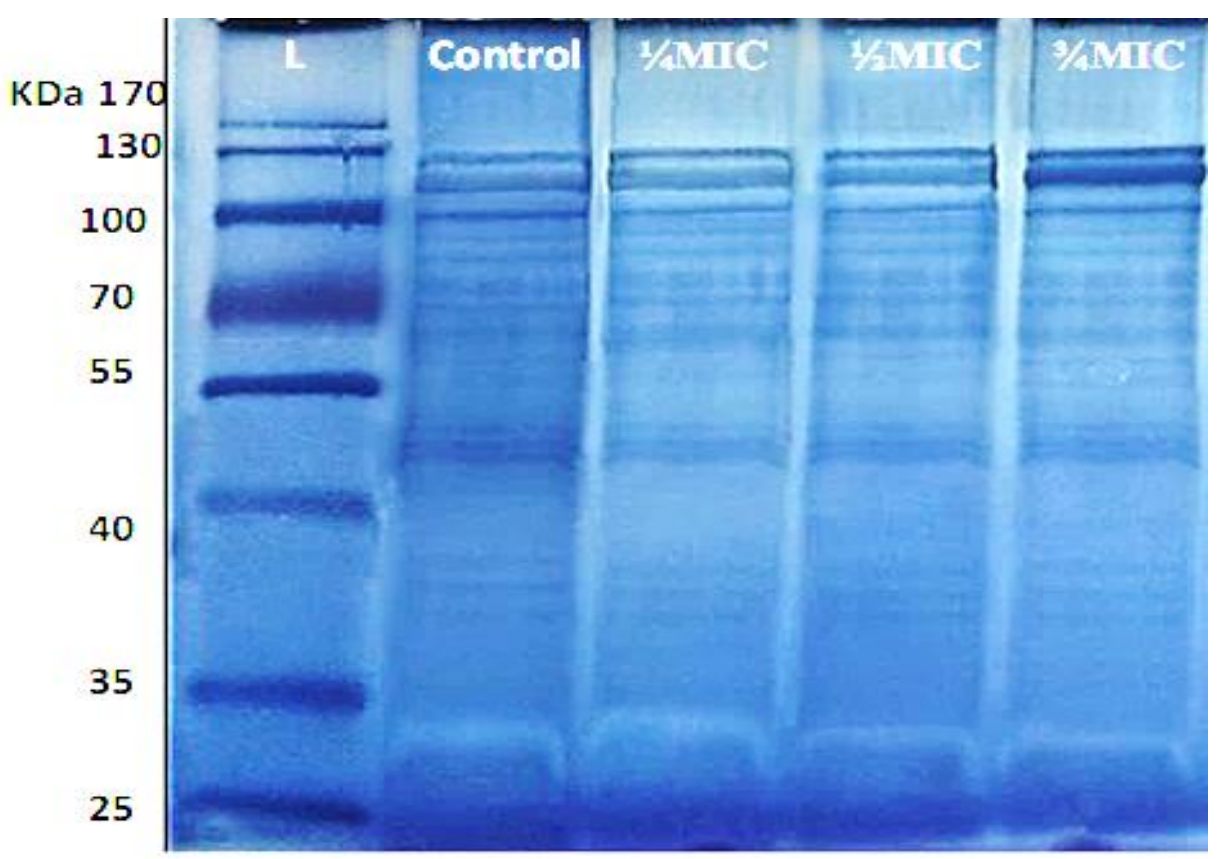

It is seemed that there are two opposite results but it may be deduced that the different composition of tested natural products/extracts may affect the phospholipase regulation in more than one regulatory mechanism through QS systems. Surely, this point need further experiments and research.

The present results also revealed that guava leaves extract at sub inhibitory concentration $(1 / 2 \quad$ MIC) showed inhibition of biofilm formation in congo red agar. The possibility that the observed biofilm inhibitory effect was related to quorum sensing inhibition (QSI) effect of guava leaves components such as polyphenols, tannin, triterpernoids and guaijaverin.

Both quorum sensing and biofilm formation are important in the pathogenesis of $P$. aeruginosa infections. Quorum sensing regulates many different functions and its control of these functions can change depending on environmental conditions.Supporting this notion, several different quorum sensing-regulated functions have been shown to impact biofilm formation at different stages. (Mary et al., 2006).

Another goal of this study is to investigate the mode of action of Psidium guajava (guava) leaves extract on the outer membrane proteins of MDR isolate of $P$. aeruginosa. Sub inhibitory conc. ( $1 / 2$ MIC) of guava leaves extract showed lower relative density in protein bands at molecular weight of 107 $\mathrm{KDa} \& 89 \mathrm{KDa}$ in comparison to the control while $3 / 4$ MIC of guava leaves extract showed lower relative density in protein bands at molecular weights of $70 \mathrm{KDa}, 65 \mathrm{KDa}, 60$ KDa, 59 KDa, 49 KDa,44 KDa\& 36 KDacompared to the control.The protein bands of estimated molecular weights of 70,44 and $38 \mathrm{KDa}$ are most likely representing the porin proteins $\mathrm{Opr} \mathrm{C}, \mathrm{E}$ and $\mathrm{F}$ respectively (Eisaku and Taiji,1989). Decreasing the relative density in relation to the control indicated downregulation in expressed protein and may point to a mechanism leading to bacterial death. Guava leaves composed of different components such as polyphenols which may be 
responsible of resulted changes in outer membrane proteins of MDR $P$. aeruginosa isolate.

Researchers are increasingly investigating herbal products for new anti-pathogenic agents that might act as nontoxic QS inhibitors, thus controlling infections without encouraging the appearance of resistant bacterial strains (Hentzer and Givskov, 2003). QS inhibition, results in reduction of bacterial virulence and control of infection, So that the host immune system can clear out the bacteria. since bacterial growth is not affected by QS inhibitors, the developmentof resistance risk will be lower (González and Keshavan, 2006).

\section{References}

Alexandra, W. 2009. Worden Lab. DNA Extraction CTAB Method.

Anderson, D.M. and Frank, D.W. 2012. Five mechanisms of manipulation by bacterial effectors: a ubiquitous theme. PLoS Pathog., 8:e1002823. doi:10.1371/journal.ppat.1002823.

Balasubramanian, D., Schneper, L., Kumari, H. and Mathee, K. 2013. A dynamic and intricate regulatory network determines Pseudomonas aeruginosavirulence. Nucleic Acid Res., 41:1-20.

Bardoel, B.W., van der Ent, S., Pel, M.J., Tommassen, J., Pieterse, C.M.,van Kessel, K.P. and van Strijp, J.A. 2011.Pseudomonas evades immune recognition of flagellin in both mammals and plants. PLoS Pathog., 7(8):1-11.

Bhaskarwar, B., Itankar, P. and Fuluke, A. 2008. Evaluation of antimicrobial activity of medicinal plant Jatropha podagrica (Hook). Rom Biotechnol Lett., 13(5): 3873-3877.

Burns, and Clark. 1992. Salicylate-Inducible Antibiotic Resistance in Pseudomonas cepaciaAssociated with Absence of a Pore-Forming Outer Membrane Protein, Antimicrobial Agents And Chemother.,
36(10): 2280-2285.

Burt, S. and Reinders, R.D. 2003. Antibacterial activity of selected plant essential oils against Escherichia coli O157: H7. Lett. Appl. Microbiol., 36: 162-167.

Burt, S. 2004. Essential oils: their antibacterial properties and potential applications in foods - A review. Int. J. Food Microbiol. 94: 223-253.

Caiazza, N.C., Shanks, R.M., O'Toole, G.A. 2005. Rhamnolipids modulate swarming motility patterns of Pseudomonas aeruginosa. J. Bacteriol. 187 (21): 73517361.

Carson, C.F., Cookson, B.D. and Riley, T.V., 1995.Susceptibility of methicillinresistant Staphylococcus aureus to the essential oils of Melaleuca alternifolia. $J$. Antimicrobial Chemother., 35: 421-424.

Carson, C.F., Mee, B.J. and Riley, T.V. 2002. Mechanism of action of Melaleuca alternifolia (tea tree) oil on Staphylococcus aureus determined by time-kill, lysis, leakage, and salt tolerance assays and electron microscopy. Antimicrob. Agents Chemother., 46: 1914-1920.

CheO'May and Nathalie Tufenkji. 2011. The Swarming Motility of Pseudomonas aeruginosa Is Blocked by Cranberry Proanthocyanidins and Other TanninContaining Materials, Appl. Environ. Microbiol., 77(9): 3061-3067.

Choi, H.J. and Kim, M.H. 2013. Improved PCR for identification of Pseudomonas aeruginosa, Appl. Microbiol. Biotechnol., 97: 3643-3651.

CLSI-Clinical and Laboratory Standards Institute. 2014. Performance Standards for Antimicrobial Susceptibility Testing; Twenty-Fourth Informational Supplement. CLSI document M100-S24.

Deng, Q. and Barbieri, J.T. 2008.Molecular mechanisms of the cytotoxicity of ADPribosylating toxins. Annu. Rev. Microbiol. 62:271-288.

Deziel, E., Lepine, F., Milot, S. and Villemur, R. 2003. rhlA is required for the production of a novel biosurfactant 
promoting swarming motility in Pseudomonas aeruginosa: 3-(3hydroxyal- kanoyloxy)alkanoic acids (HAAs), the precursors of rhamnolipids. Microbiol., 149: 2005-2013.

Difco, BBL Manual, 2009. Manual of Microbiological Culture Media, 2nd edition, Becton Dickinson and Company. Maryland. USA: 402-403.

Eisaku Yoshihara and TaijiNak. 1989. Identification of porins in the outer membrane of pseudomonas aeruginosa that form small diffusion pores, the $J$. Biol. Chem., 264(11): 6297-6301.

Engel, J. and Balachandran, P. 2009. Role of Pseudomonas aeruginosa type III effectors in disease. Curr. Opinion in Microbiol., 12: 61-66.

Fernandez-Patron, C., Castellanos-Serra, L. and Rodriguez, P. 1992.Reverse staining of sodium dodecyl sulfate polyacrylamide gels by imidazole-zinc salts: Sensitive detection of unmodified proteins. Biotechniques, 12: 564-573.

Freeman, J., Falkiner, F.R. and Keane, C.T.1989. New method for detecting slime production by coagulase negative staphylococci. J. Clin. Pathol., 42: 872-4.

González, J.E. and Keshavan, N.D. 2006. Messing with bacterial quorum sensing. $J$. Microbiol. Mol. Biol. Rev., 70(4):859-75.

Han, Y.C., Teng, C.Z., Hu, Z.L. and Song, Y.C. 2008. An optimal method of DNA silver staining in polyacrylamide gels Electrophoresis, 29:1355-1358.

Hentzer, M. and Givskov, M. 2003. Pharmacological inhibition of quorum sensing for the treatment of chronic bacterial infections. J. Clin. Invest., 112: 1300-1307.

Hoeniger, J.F.M.1964. Cellular changes accompanying the swarming of Proteus mirabilis.I. Observation of living cultures. Can. J. Microbiol., 10: 1-9.

Horvat, R.T. and Parmely, M.J. 1988.Pseudomonas aeruginosa alkaline protease degrades human gamma interferon and inhibits its bioactivity. Infect Immun., 56: 2925-2932.
Jaeger, K.E., Schneidinger, B., Liebeton, K., Haas, D., Reetz, M.T., Philippou, S., Gerritse, G., Ransac, S., and Dijkstra, B.W. $1996 . \quad$ Lipase of Pseudomonasaeruginosa: molecular biology and biotechnological application. In Molecular Biology of Pseudomonas. Nakazawa, T., Furukawa, K.,Haas, D., and Silver, S. (eds). American Society for Microbiology Press : 319-330.

Jan Hudzicki, 2009. Kirby-Bauer Disk Diffusion Susceptibilit y Test Protocol, american society for microbiology, http://www. microbelibrary.org /library/laboratory test/3189-kirby-bauer disk-diffusionsusceptibility test-protocol.

Ji, Y.T., Qu, C.Q. and Cao, B.Y. 2007. An optimal method of DNA silver staining in polyacrylamide gels Electrophoresis. 28:1173-1175.

Karuppusamy, S. and Rajasekaran, K.M. 2009. High Throughput Antibacterial Screening of Plant Extracts by Resazurin Redox with Special Reference to Medicinal Plants of Western Ghats. Global J. Pharmacol., 3(2): 63-68.

Kumar Bajaj, B. and Jamwal, G. 2013. Thermostable alkaline protease production from Bacillus pumilusD-6 by using agro-residues as substrates. Advances in Enzyme Research. 1 (2):3036.

Kusum, H., Ravi, K. and Himanshi, S.2014. Attenuation of quorum sensing controlled virulence of Pseudomonasaeruginosa by cranberry. Indian J. Med. Res. 139: 446453.

Mary, J.o. and Matthew, R. 2006. Does Pseudomonasaeruginosa use intercellular signalling to build biofilm communities?, Cellular Microbiology. 8(12): 18411849.

Matsuyama, T., Takagi, Y., Nakagawa, Y., Itoh, H., Wakita, J. and Matsushita, M. 2000. Dynamic aspects of the structured cell population in swarming colony of Proteus mirabilis. J. Bacteriol. 182:385- 393.

McMurray, W.C. and Magee, W.L.1972. 
Phospholipid metabolism. Annu. Rev. Biochem. 41: 129-160.

Meyers, D.J. and Berk, R.S. 1990. Characterization of phospholipase C fromPseudomonasaeruginosa as a potent inflammatory agent. Infect Immun. 68 : 659-66.

Monica Cheesbrough, 2006 district laboratory practice in tropical countries, Cambridge University Press.2:1-434.

Nowsheen, H. and Jain, S.K. 2008. Characterization of an Outer Membrane Protein of Salmonella entericaSerovar Typhimurium That Confers Protection against Typhoid. Clin. vaccine immunol., 15(9):1461-1471.

Ochsner, U.A. and Reiser, J. 1995.Autoinducermediated regulation of rhamnolipidbiosurfactant synthesis in Pseudomonasaeruginosa. Proc. Natl. Acad. Sci., USA.92:6424-6428.

Ochsner, U.A., Koch, A.K., Fiechter, A. and Reiser, J. 1994. Isolation and characterization of a regulatory gene affecting rhamnolipidbiosurfactant synthesis in Pseudomonas aeruginosa. $J$ Bacteriol., 176:2044-2054.

Okigbo, R.N. and Ogbonnaya, U.O. 2006. Antifungal effects of two tropical plant leaf extracts (Ocimumgratissimum and Aframomummelegueta) on post harvest yam (Dioscorea spp.) rot. Afr. $J$. Biotechnol. 5: 727-731.

Parmely, M., Gale, A., Clabaugh, M., Horvat, R. and Zhou, W.W.1990. Proteolytic inactivation of cytokines by Pseudomonas aeruginosa. Infect Immun., 58: 30093014.

Pearson, J.P., Passador, L., Iglewski, B.H. and Greenberg, E.P. 1995. A second Nacylhomoserine lactone signal produced by Pseudomonasaeruginosa. Proc. Natl. Acad. Sci. USA, 92:1490-1494.

Price, M.F., Wilkinson, I.D. and Gentry, L.O.1982.Plate method for detection of phospholipase activity in Candida albicans. Sabouraudia. 20: 7-14.

Rauprich, O., Matsushita, M., Weijer, C.J., Siegert, F., Esipov, S.E. and Shapiro,
J.A.1996. Periodic phenomena in Proteus mirabilisswarm colony development. $J$. Bacteriol., 178:6525-6538.

Reischl, U., Linde, H.J., Metz, M., Leppmeier, B. and Lehn, N. 2000.Rapid dentification of methicillin-resistant Staphylococcus aureus and simultaneous species confirmation using real-time fluorescence PCR. J. Clin. Microbiol., 38: 2429-2433.

Robert, R., Joseph, R., Diana, R., Kamal, K., Rachel, C., Nicholas, T., Oksana, D., and Jeffrey, M. 2005. Bacterial Communication ("Quorum Sensing”) via Ligands and Receptors: A Novel Pharmacologic Target for the Design of Antibiotic Drugs. J. Pharmacol. Exp. Ther., 312(2): 417-423.

Sambrook, J., Russell, D.W. 2001. Molecular Cloning: A laboratory manual,. 3rd ed. Cold Spring Harbor Laboratory Press. New York.

Schauder, S. and Bassler, B.L.2001. the language of bacteria. Genes Develop., 15:1468-1480.

Schoenborn, J.R. and Wilson, C.B. 2007. Regulation of interferon-gamma during innate and adaptive immune responses. Adv. Immunol., 96: 41-101.

Schroder, K., Hertzog, P.J., Ravasi, T. and Hume, D.A. 2004. Interferon-gamma: an overview of signals, mechanisms and functions. J. Leukoc. Biol., 75:163-189.

Shariff, N., Sudarshana, M.S., Umesha, S. and Hariprasad, P. 2006. Antimicrobial activity of Rauvolfiatetraphylla and Physalisminima leaf and callus extracts. Afr. J. Biotechnol., 5: 946-950.

Shrestha, N..K, Tuohy, M.J., Hall, G.S., Isada, C.M. and Procop, G.W.2002.Rapid identification of Staphylococcus aureus and themec Agene from BacT/ALERT blood culture bottles by using the Light Cycler system. J. Clin. Microbiol., 40: 2659-2661.

Siegmund, I. and Wagner, F. 1991. New method for detecting rhamnolipids excreted by Pseudomonas species during growth on mineral agar. Biotechnology techniques, 5(4): 265-268. 
Sophie, B., Chantal, S., Patricia, N., Andre'eLazdunski, and Alain, F. 2005. Quorum sensing negatively controls type iii secretion regulon expression in pseudomonas aeruginosa PAO1. J. bacterial., 187 (11): 3898-3902.

Tiago, F. and Wayne, R. 2012. ImageJ User Guide, IJ 1.46r.

Tremblay, J., Richardson, A., Lepine, F. and Déziel, E.2007. Self-produced extracellular stimuli modulate the Pseudomonas aeruginosa swarming motility behavior. Environ. Microbiol., 9:2622-2630.

Tyagi, A.K. and Malik, A.2010. Liquid and vapour-phase antifungal activities of selected essential oils against Candidaalbicans. BMC Complementary and Alternative Med., 10: 65.

Uniyal, S.K., Singh, K.N., Jamwal, P., Lal, B. 2006. Traditional use of medicinal plants among the tribal communities of Chhota Bhangal.Western Himalayan. $J$. Ethnobiol. Ethnomed., 2: 1-14.

Van Delden, C.2007. Pseudomonas aeruginosa bloodstream infections: how should we treat them? Int. J. Antimicrob Agents, 30(1): 71-75.

Vijay, K., Davender, K., Lalit, K., Sushil, N., Chand, R. and Rajinder, P. 2012. Screening, isolation and production of lipase/esterase producing Bacillus $s p$. strain DVL2 and its potential evaluation in esterification and resolution reactions, Arch. Appl. Sci. Res., 4(4):1763-1770.
Warburg, O. and Christian, W. 1941.Isolierung und Kristallisation des Garungsferments Enolase. Biochem. Z,. 310: 384-421.

Winson, M.K., Camara, M., Latifi, A., Foglino, M., Chhabra, S.R., Daykin, M., Bally, M., Chapon, V., Salmond, G.P.C., Bycroft, B.W., Lazdunski, A., Stewart, G. and Williams, P. 1995. Multiple N-acyl-Lhomoserine lactone signal molecules regulate production of virulence determinants and secondary metabolites in Pseudomonas aeruginosa. Proc. Natl. Acad. Sci. USA, 92: 9427-9431.

Winson, M.K., Camara, M., Latifi, A., Foglino, M., Chhabra, S.R., Daykin, M., Bally, M., Chapon, V., Salmond, G.P.C., Bycroft, B.W., Lazdunski, A., Stewart, G.S. and Williams, P. 1995. Multiple N-acyl-Lhomoserine lactone signal molecules regulate production of virulence determinants and secondary metabolites in Pseudomonas aeruginosa. Proc. Natl. Acad. Sci. USA, 92: 9427-9431.

Yosuke, T. and Yutaka, Y.2013. Interspecies Interaction between Pseudomonas aeruginosa and Other Microorganisms. Microbes Environ., 28(1): 13-24.

Zulianello, L., Canard, C., Köhler, T., Caille, D., Lacroix, J.S. and Meda, P. 2006.Rhamnolipids are virulence factors that promote early infiltration of primary human airway epithelia by Pseudomonas aeruginosa. Infection and Immunity, 74: 3134-3147.

\section{How to cite this article:}

Ahmed Ahmed Abd El-Aziz, Tarek El-Said El-Banna, Fatma Ibrahim Sonbol and Shymaa Mohamed Sallam. 2017. Anti-Virulence Activity of Selected Natural Products against Pseudomonas aeruginosa. Int.J.Curr.Microbiol.App.Sci. 6(1): 396-410. doi: http://dx.doi.org/10.20546/ijcmas.2017.601.048 